\title{
Perubahan Sosial Masyarakat di Jazirah Arab: Transformasi Kultural Ashabiyah dalam Menunjang Kekuasaan Nabi Muhammad
}

\author{
Muhamad Yusrul Hana \\ Sekolah Tinggi Ilmu Budaya Islam Syekh Jangkung Pati \\ yusrulhana33@gmail.com
}

\begin{abstract}
Ashabiyah has become one of the important social systems for people in the Arabian Peninsula before the Prophet Muhammad introducing Islam to Mecca. Ashabiyah brought the tribes into one strong unity in Arab, though it turned out this system often leads to egoism and aggression of each group, which caused dispute and war. The Prophet Muhammad then used this system to unify the people of the desert and the people within the country once again with a new purpose, which is Islam, after Islam came into Arabic. The primary purpose of the ashabiyah system was unification and sovereignty for all the people, and it costs the system to have a guideline of religious values. So, based on the values every act made by the tribe will lead to right action as well. This research wants to explain how did Ashabiyah take a role in all peoples of Arabia and be a succession of Prophet Muhammad (PBUH) in the spread of Islam. The method that is used in this study is that historical research contains heuristic, criticism, interpretation, and historiography. The results of the study showed that the ashabiyah based on Islam became a strong system in building the progress of the ummah because, without social solidarity, unity, and help, the ideals of sovereignty could not be realized.
\end{abstract}

Keywords: ashabiyah; social solidarity; social system.

\begin{abstract}
Abstrak
Ashabiyah telah menjadi satu bentuk sistem sosial penting dalam masyarakat di Jazirah Arab sebelum Nabi Muhammad SAW membawa Islam ke Makkah. Ashabiyah membawa kabilahkabilah di Jazirah Arab ke dalam persatuan yang kuat, meskipun sistem ini sering menjurus pada agresifitas ego masing-masing kelompok yang menyebabkan pertikaian dan peperangan. Setelah adanya Islam, persatuan sistem sosial ini dipakai oleh Nabi Muhammad SAW untuk menyatukan seluruh penduduk gurun pasir dan penduduk negeri dalam satu tujuan sama, yaitu Islam. Karena tujuan utama dari ashabiyah adalah persatuan dan kedaulatan bagi semua orang, maka sistem ini harus berpedoman pada nilai-nilai agama agar tindakan kabilah-kabilah menjurus kepada kebaikan. Penelitian ini ingin menjelaskan peran ashabiyah dalam seluruh aspek kehidupan bangsa Arab dan menjadi suksesi Nabi Muhammad saw. dalam penyebaran Islam. Metode yang digunakan dalam penelitian ini adalah metode penelitian sejarah meliputi heuristik, kritik, interpretasi, dan historiografi. Hasil penelitian menunjukkan, ashabiyah yang berlandaskan Islam menjadi sistem yang kuat dalam membangun kemajuan umat, karena tanpa adanya solidaritas sosial, persatuan, dan tolong-menolong tidak mungkin cita-cita kedaulatan dan kekuasaan Nabi Muhammad saw. dapat terwujud.
\end{abstract}

Kata kunci: ashabiyah; solidaritas sosial; sistem sosial.

\section{A. Pendahuluan}

Manusia merupakan makhluk yang membutuhkan organisasi kemasyarakatan untuk menunjang kemajuan kehidupannya. Menurut para filosof (al-hukma'), manusia merupakan makhluk yang bersifat politis, jadi mereka memerlukan sebuah organisasi kemasyarakatan dalam bentuk tradisional maupun modern. Dengan adanya organisasi kemasyarakatan dalam bentuk yang lebih mapan seperti kota, sebagai wadah manusia bergerak memenuhi kebutuhannya, maka manusia sesungguhnya telah menciptakan sebuah peradaban ('umran). Ibnu Khaldun menyatakan bahwa peradaban merupakan kodrat manusia, karena manusia hidup 
tidak cukup untuk memperoleh makanan. Manusia dalam memperoleh makanan, tentu akan membutuhkan alat-alat untuk mengolah, maka mereka membutuhkan tenaga dan pikiran lebih untuk menciptakan sebuah alat atau system. Guna memenuhi kebutuhan hidupnya, jelas manusia membutuhkan bantuan orang lain. Mereka harus berabung dengan manusia lainnya

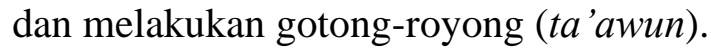

Tatkala umat manusia telah mencapai organisasi kemasyarakatan yang mapan atau disebut sebagai peradaban kota, tentu membutuhkan seseorang yang akan memlihara mereka. Jika tidak ada seseorang berwibawa yang memlihara, maka sifat hewani yang ada pada diri manusia, akan merusak sebuah organisasi dan peradaban yang telah ada. Oleh karena itu, seseorang yang dapat memimpin masyarakat merupakan orang yang berada dalam kelompok itu, harus mampu menguasai mereka, mempunyai kekuatan, dan wibawa lebih dari mereka. Hal ini yang disebut oleh Ibnu Khaldun sebagai kekuasaan (mulk). ${ }^{1}$ Guna memperkuat kelangsungan kekuasaan tersebut, seorang penguasa harus memiliki peraturan-peraturan dalam sebuah kabilah. Selain peraturan sebagai landasan konsensus, penguasa juga bisa menggunakan bantuan solidaritas sosial (ashabiyah) untuk memaksa orang lain agar mengikuti keinginan penguasa.

Perlu dipahami bahwa ashabiyah berasal dari kata ashab yang berarti hubungan dan kata ishab yang berarti ikatan. Dengan demikian, ashabiyah menunjukkan adanya ikatan mental yang menghubungkan orang-orang yang mempunyai hubungan kekeluargaan. Dalam masyarakat Arab, ashabiyah dikatakan sebagai sistem sosial yang dianut oleh masyarakat yang menekankan pada pembelaan keluarga dan mempertahankan semampu mungkin orang-orang yang tergabung di dalamnya. Orang-orang yang dianggap satu kelompok ashabiyah adalah mereka yang masih dalam garis keturunan bapak, karena mereka adalah orang-orang yang membela keluarga di atasnya. ${ }^{2}$ Menurut Ibnu Khaldun, ashabiyah mempunyai pengertian yang lebih luas, tidak hanya hubungan kekluargaan saja tetapi meliputi hubungan atas dasar persekutuan, perbudakan (mawali), dan penyewaan tentara. ${ }^{3}$

Ashabiyah menurut Ibnu Khaldun memiliki makna negatif pada masa sebelum Islam, karena menekankan pada timbulnya kesombongan, takabur dan keinginan bergabung pada suku yang kuat dan terhormat, dan tidak berdasar pada persatuan keagamaan. Artinya semua perilaku ashabiyah hanya didasarkan atas nafsu keduniawian. Namun, pengertian ini mengalami degradasi semasa Islam yang dibawa Nabi Muhammad SAW. Nabi SAW mengkompromikan ashabiyah dengan prinsip-prinsip Islam yang berlandaskan persatuan keagamaan. Menurut Ali Nasyat, ashabiyah semasa Islam berlandaskan perasaan persaudaraan dan saling mengasihi yang berkembang dalam kalangan individu yang membentuk satu solidaritas sosial.

Menurut Abdul Raziq al-Makki dalam buku al-Fikr al-Falsafi Inda Ibnu Khaldun, ashabiyah mempunyai 5 bentuk. Pertama, hubungan kekerabatan dan keturunan, ini adalah ashabiyah paling kuat. Kedua, persekutuan yang terjadi karena keluarnya seseorang dari garis keturunannya ke garis keturunan orang lain. Ketiga, kesetiaan yang terjadi karena peralihan dari satu garis keturunan dan kekerabatan ke keturunan lain karena kondisi sosial. Keempat, penggabungan yaitu larinya seseorang dari keluarga dan kabilahnya dan bergabung pada keluarga dan kabilah lain. Kelima, perbudakan yang timbul dari hubungan antara para budak dan kaum mawāli dengan majikan-majikan mereka. ${ }^{4}$ Maka jelaslah bahwa ashabiyah tidak hanya didasarkan pada satu hubungan kekeluargaan saja, tetapi mempunyai solidaritas sosial

${ }^{1}$ Ibnu Khaldun, Muqaddimah, terj. Ahmadie Thoha (Jakarta: Pustaka firdaus, 2008), 74.

'Zainab al-Khudhari, Filsafat Sejarah Ibnu Khaldun, terj. Ahmad Rofi' Utsmani (Bandung: Pustaka, 1979), 141.

${ }^{3}$ Ibid., 143.

${ }^{4}$ Ibid., 146. 
yang lebih luas akibat sebuah interaksi dan komunikasi yang terjalin diantara individu atau kelompok.

Kelompok manusia yang hidup dalam sebuah solidaritas social memiliki perbedaan mendasar tergantung mereka memperoleh penghidupannya. Di antara kelompok manusia yang bertani, menanam sayuran, buah-buahan, dan memlihara binatang, mereka harus hidup di tanah yang luas. Oleh karena itu, mereka diharuskan melakukan aktifitas di padang yang luas. Kehidupan mereka berlandaskan rasa saling membantu dalam memenuhi kebutuhan hidup dan peradaban. Namun, dalam kelompok solidaritas sosial yang ada, mereka terbagi menjadi dua, pertama, kelompok ashabiyah yang belum bisa memperoleh lebih dari batas kebutuhan hidup, karena mereka tidak mampu memperoleh lebih dari itu. Ibnu khaldun menyebutnya sebagai Umran Badawi (komunitas tradisional). ${ }^{5}$ Kedua, kelompok ashabiyah yang mampu memperoleh kekayaan dan kemewahan di atas yang mereka butuhkan. Ibnu Khaldun menyebutnya sebagai Umran Hadhiri (komunitas modern). ${ }^{6}$ Perbedaan ini didasarkan pada bagian bumi di mana mereka tinggal, karena dipengaruhi oleh tanah dan iklim yang ada.

Jazirah Arab secara geografi terbagi menjadi dua bagian dataran, yaitu dataran tandus atau gersang dan dataran subur. Masyarakat yang hidup dalam tanah yang gersang, seperti di Arab bagian Tengah, mereka biasanya hidup secara berpindah-pindah (nomaden) untuk mencari daerah subur. Kabilah-kabilah yang hidup di tanah gersang, memiliki watak sosial yang keras. Hal ini disebabkan oleh pengaruh geografi di mana mereka diubah menjadi orang-orang yang suka berperang guna memperebutkan daerah subur sebagai tempat tinggal kabilah mereka.

Masyarakat yang hidup di tanah subur, seperti di Arab bagian selatan dan di sepanjang pesisir pantai, mereka menjalani hidup dengan bersosialisasi lebih dinamis, bahkan terhadap orang asing. Kemapanan ekonomi akibat keadaan geografi yang stabil, membuat peradaban kabilah-kabilah di daerah ini menjadi lebih maju. Apalagi daerah-daerah mereka sering didatangi tamu dan pedagang dari luar kota untuk bersinggah. Akibat daripada itu, kehidupan ekonomi dan politik kabilah-kabilah di sana banyak mengalami kestabilan. Kabilah-kabilah yang tinggal di tanah tandus dan subur sama-sama disatukan ikatan keturunan yang sangat kuat dalam bentuk ashabiyah (solidaritas sosial). Mereka selalu mengedepankan persatuan sama rasa antar kelompok kabilahnya dalam suka maupun duka. Dalam artian bahwa kesakitan dan kebahagiaan satu kabilah bisa dirasakan anggota kabilah lainnya. Pertalian darah yang kuat seperti ini, bisa membawa mereka dalam bahaya atau meninggalkan mereka dari bahaya itu sendiri.

Akhirnya, ikatan ashabiyahlah yang membentuk karakter sosial kabilah-kabilah di Arab sebelum Islam. Mereka juga merasa kabilah-kabilah di Arab lah yang paling kuat di antara kabilah lain di dunia, karena kekuatan solidaritas sosial, persaudaraan, dan nasabnya. Selain itu, kabilah-kabilah di Arab juga menonjol dalam kepandaian bersyair, berperang, berkuda, dan memanah. Namun tidak jarang juga karena ikatan solidaritas internal kekabilahan ini, peperangan sering terjadi di antara kabilah-kabilah di Arab itu sendiri. Meskipun dalam beberapa peperangan tidak sampai menimbulkan korban jiwa.

Ashabiyah di satu sisi mempunyai makna positif bagi peradaban yang menunjukkan persatuan dan persaudaraan. Hal inilah yang mendorong terciptanya keadilan sosial dan membangkitkan semangat memajukan peradaban. Namun sisi negatif dari ashabiyah adalah fanatisme yang berlebihan tanpa melihat kebenaran dan membutakan mereka terhadap nilainilai dan moral baik keagamaan. ${ }^{7}$ Mereka biasanya sesuka hati melawan suku-suku lain tanpa

\footnotetext{
${ }^{5}$ Theguh Saumantri and Abdillah Abdillah, "Teori Ashabiyah Ibnu Khaldun Sebagai Model Perkembangan Peradaban Manusia,” Jurnal Tamaddun : Jurnal Sejarah dan Kebudayaan Islam 8, no. 1 (2020).

${ }^{6}$ Ibid.

${ }^{7}$ Abbas Sofwan Matlail Fajar, "Perspektif Ibnu Khaldun Tentang Perubahan Sosial," SALAM: Jurnal Sosial dan Budaya Syar-i 6, no. 1 (2019): 1-12.
} 
berlandaskan agama, bahkan dalam al-Fatwa al-Khairiyyah persaksian atas dasar ashabiyah karena seseorang membenci orang lain dan orang tersebut masuk dalam kelompok A atau B tidak akan diterima dan di haramkan. ${ }^{8}$ Setelah adanya Islam, peran ashabiyah masih terbilang terlihat jelas. Kekuatan ashabiyah secara umum telah membantu Nabi SAW untuk menyebarkan Islam di Arab. Nabi saw. dan Islam telah memperkuat solidaritas sosial antar masing-masing kelompok ashabiyah dan juga mempersatukan kelompok kabilah yang bertentangan di Jazirah Arab di bawah payung agama Islam.

Penelitian ini penting dilakukan guna mengelaborasi lebih mendalam persoalan ashabiyah di Jazirah Arab. Sebagai sebuah sistem sosial yang mapan, ashabiyah telah menjelma menjadi sebuah konsep persatuan dalam sebuah kabilah. Meskipun proses persatuan yang ada, tidak selalu dibarengi dengan dampak kemaslahatan dan kedaulatan yang memihak kepada masyarakat. Namun, Nabi saw. secara simultan mampu menyempurnakan konsep ini menjadi lebih mapan. Untuk memahami alur sejarah dan alur sosial transformasi kemapanan ashabiyah dari masa sebelum Islam sampai masa Nabi saw, perlu adanya elaborasi agar alur transformatif yang terjadi dapat dipahami secara kronologis.

Kajian tentang ashabiyah dalam pemikiran Ibnu Khaldun telah dilakukan beberapa peneliti sebelumnya, seperti karya Abbas Sofwan Matlail Fajar ${ }^{9}$ yang menitikberatkan pada pemikiran Ibnu Khaldun tentang konsep perubahan sosial masyarakat Arab dari fase masyarakat primitif menuju masyarakat modern yang mana perubahan ini juga dibarengi dengan kemunculan, perkembangan, dan kemunduran suatu bangsa dalam teori siklusnya Ibnu Khaldun. Karya Hanna Widayani ${ }^{10}$ yang menitikberatkan pada relevansi solidaritas sosial yang diutarakan Ibnu Khaldun dengan tujuan nasionalisme dalam artian bangsa Indonesia. Karya Muh. Ilham ${ }^{11}$ yang menitikberatkan pada pentingnya menggunakan konsep ashabiyah dalam menjaga stabilitas dan kekuatan negara dan jika ashabiyah memudar, maka akan berpotensi melemahkan ketahanan negara itu. Karya Syafrizal ${ }^{12}$ yang menitikberatkan persamaan nasionalisme dan ashabiyah sebagai alat pemersatu bangsa guna mengatasi seluruh permasalahan bangsa Indonesia. Terakhir karya Theguh Saumantri ${ }^{13}$ yang menitikberatkan pada kegunaan system ashabiyah sebagai cikal-bakal sebuah perkembangan peradaban manusia dari komunitas tradisional dengan kehidupan yang sederhana, menuju komunitas modern dengan kehidupan yang lebih kompleks dengan berbagai kemajuan dan kemewahan yang ada.

Penelitian-penelitian sebelumnya secara eksplisit menitikberatkan pada pentingnya penggunaan ashabiyah dalam pembentukan peradaban manusia yang berujung pada kemapanan komunitas yang berpangkal pada kemodernan, sebagai penunjang membentuk sebuah lembaga besar yang dinamakan negara. Namun, penelitian-penelitian sebelumnya belum menjelaskan bahwa konsep ashabiyah telah membentuk tipologi masyarakat di Jazirah Arab dengan karakter sosial yang berbeda-beda. Dengan datangnya Islam yang dibawa Nabi saw, ashabiyah bertransformasi menjadi media pemersatu, mendukung kejayaan Islam, dan menunjang kedaulatan dan kemaslahatan umat dibawah kekuadaan Nabi Muhammad SAW.

${ }^{8}$ Al-Khudhari, Filsafat Sejarah, 142.

${ }^{9}$ Fajar, "Perspektif Ibnu Khaldun Tentang Perubahan Sosial."

${ }^{10}$ Hanna Widayani, "Ashabiyah Ibnu Khaldun dan Relevansinya dengan Nasionalisme di Indonesia," Manthiq, 2, no 2, (2017): 149-162.

${ }^{11}$ Muh. Ilham, "Konsep 'ashabiyah Dalam Pemikiran Politik Ibnu Khaldun” Jurnal Politik Profetik, 04, no. 1 (2016): 1-13.

${ }^{12}$ Syafrizal, "Konsep 'Ashabiyah Ibn Khaldun dalam Penguatan Nilai Nasionalisme di Indonesia”, (Skripsi Fakultas Syariah dan Hukum, Universitas Islam Negeri Sumatera Utara, 2017).

${ }^{13}$ Saumantri and Abdillah, "Teori Ashabiyah Ibnu Khaldun Sebagai Model Perkembangan Peradaban Manusia." Tamaddun: Jurnal Sejarah dan Kebudayaan Islam, 8, no 1 (2020): 21-38. 
Maka, penelitian ini hadir untuk menganalisa permasalahan-permasalahan yang telah disebutkan dan untuk melengkapi kekurangan-kekurangan penelitian sebelumnya.

Untuk memahami secara mendalam dan menyeluruh mengenai permasalahan di atas, tulisan ini memusatkan perhatian pada beberapa pertanyaan sebagai berikut, bagaimana ashabiyah membentuk tipologi bangsa Arab?, bagaimana transformasi ashabiyah dalam menumbuhkan solidaritas sosial masing-masing kelompok kabilah di Jazirah Arab?, bagaimana proses pengaruh timbal balik ashabiyah dengan agama dan politik Islam di Jazirah Arab dalam menunjang kekuasaan Nabi Muhammad SAW?.

Berdasarkan deskripsi masalah di atas, tulisan ini bertujuan 1) menggambarkan konstruksi konsep ashabiyah dalam membentuk tipologi bangsa Arab, 2) menggambarkan transformasi ashabiyah dalam menumbuhkan solidaritas sosial masing-masing kelompok kabilah di Jazirah Arab, 3) menjelaskan proses pengaruh timbal balik ashabiyah dengan agama dan politik Islam di Jazirah Arab dalam menunjang kekuasaan Nabi Muhammad SAW. Semua tujuan dalam penelitian ini bermuara pada sintesa bahwa ashabiyah sebagai model pembentuk persatuan dan kedaulatan masyarakat Islam di Jazirah Arab.

Penelitian ini adalah library research yaitu penelitian yang dilakukan untuk memecahkan suatu masalah yang didasarkan pada penelaahan secara kritis dan mendalam terhadap sumber-sumber pustaka yang relevan dengan kajian penelitian ini terkait pengaruh konsep ashabiyah dalam masyarakat di Jazirah Arab.

Penelitian ini menggunakan 4 metode penelitian sejarah. ${ }^{14}$ Metode sejarah yang digunakan dimaksudkan untuk menguji dan menganalisa secara kritis rekaman dan peninggalan masa lampau. Empat langkah metode yang dimaksud di atas dilakukan dalam proses penelitian sebagai berikut. Pertama heuristik merupakan teknik pengumpulan data primer berupa buku karya Ibnu Khaldun berjudul al-Muqaddimah dan sumber sekunder yaitu artikel-artikel jurnal didapatkan dari beberapa e-jurnal dan buku-buku yang mengkaji tentang konsep ashabiyah. Kedua, kritik eksternal dan internal dilakukan untuk menguji kredibilitas dan kesahihan sumber. Kritik eksternal yaitu kritik untuk menguji keaslian sumber (otentisitas) yang berkaitan dengan bahan yang digunakan sumber tersebut. ${ }^{15}$ Kritik internal yaitu kritik yang dilakukan untuk menyeleksi, menguji, dan membandingkan informasi atau makna yang terkandung dalam sumber sejarah berkenaan dengan kredibilitasnya (dapat dipercaya atau tidak). ${ }^{16}$ Ketiga, interpretasi sebagai tahap penafsiran data yang telah menjadi fakta dengan menganalisis dan mensintesis fakta yang relevan. ${ }^{17}$ Interpretasi dikembangkan bersamaan dengan analisis yang didukung oleh teori-teori. ${ }^{18}$ Keempat, historiografi dilakukan untuk melaporkan hasil penelitian yang dituliskan secara sistematis dan kronologis.

Penelitian ini merupakan penelitian sejarah sosial, untuk memperdalam analisa terhadap kajian ini digunakan pendekatan sosiologi. Kemudian untuk menganalisa persoalan dalam penelitian ini diacu pada konsep perubahan sosial berdasar pada teori kritis dan teori interaksi sosial. Jurgen Habermas dalam teori kritisnya mengatakan bahwa manusia selalu mengusahakan sebuah perubahan sosial yang lebih baik. Guna menunjang sebuah perubahan sosial, manusia akan selalu bertindak berdasar pada kesadaran sosialnya. Kesadaran sosial inilah yang nantinya membentuk sikap untuk melakukan kegiatan dan komunikasi. Proses kegiatan inilah yang mengakibatkan tindakan aksi maupun komunikasi dalam bahasa, dan

${ }^{14}$ Dudung Abdurrahman, Metodologi Penelitian Sejarah Islam (Yogyakarta: Ombak, 2011), 104.

${ }^{15}$ Abd Rahman Hamid dan Muhammad Saleh Madjid, Pengantar Ilmu Sejarah (Yogyakarta: Ombak, 2015), 47.

\footnotetext{
${ }^{16}$ Ibid., 47-48.

${ }^{17}$ Kuntowijoyo, Pengantar Ilmu Sejarah (Yogyakarta: Bentang Budaya, 2001), 102.

${ }^{18}$ Abdurahman, Metodologi Penelitian, 65.
} 
berhubungan dengan praksis dan rasionalitas masyarakat. ${ }^{19}$ Oleh karena itu, Nabi saw. selalu melakukan proses komunikasi dengan masyarakat Jazirah Arab dalam mengubah sistem sosial ashabiyah menjadi kaya akan nilai-nilai Islam.

Perubahan sosial yang akan diusahakan oleh Nabi saw. tentu tidak berasal dari masyarakat dengan ruang kosong. Segala macam proses yang akan terjadi dalam suatu perubahan akan menemui pertentangan dan kekerasan dari sebuah komunitas masyarakat yang sudah mempunyai system sosial dan kultural. Oleh karena itu, kegiatan aksi yang dikatakan oleh Habermas, harus mengutamakan peran struktur komunikasi dalam perubahan masyarakat dengan asumsi bahwa masyarakat hakikatnya bersifat komunikatif. ${ }^{20}$ Jadi, Nabi SAW harus melakukan perubahan sosial di Jazirah Arab dan menggiring masyarakat dalam perintahnya, jika tidak ada proses tindakan komunikatif yang dilakukan. Proses tindakan komunikasi akan berjalan beriringan dengan terbentuknya pencerahan kultural dalam dunia kebudayaan, masyarakat, dan kepribadian.

Tindakan komunikasi tentu harus berdasar pada proses interaksi sosial. Interaksi sosial adalah hubungan timbal balik individu dengan individu, individu dengan kelompok atau kelompok dengan kelompok yang saling dipengaruhi tingkah laku reaktif pihak satu dan menimbulkan reaksi balik dari pihak lainnya. ${ }^{21}$ Karena interaksi sosial merupakan hal dasar dalam membentuk komunikasi, maka interaksi sosial menjadi satu bagian penting dalam kehidup masyarakat. Menurut Gillin dan Gillin interaksi sosial adalah cara berhubungan karena bertemunya seseorang dengan yang lainnya dalam menentukan sistem serta bentuk hubungan atau apa yang terjadi selanjutnya. ${ }^{22}$ Oleh karena itu, proses interaksi dan komunikasi sosial yang dilakukan Nabi SAW dengan masyarakat di Jazirah Arab, bersifat dinamis mengikuti berbagai perkembangan kepentingan seperti sosial, ekonomi, maupun politik. Oleh karena itu, kedinamisan kehidupan sosial ini membuat interaksi sosial antara Nabi SAW dan masyarakat di Jazirah Arab sering menuju derajat keekstriman atas reaksi perubahan structural yang terjadi. Maka dari itu, perlu adanya pemahaman terkait tipe-tipe penduduk Bangsa Arab sebelum Islam guna memahami dasar proses interaksi mereka dengan individu atau kelompok lainnya.

\section{B. Tipologi Penduduk Bangsa Arab Sebelum Islam}

Jazirah Arab yang menjadi tempat tumbuh dan berkembangnya Islam, dahulunya merupakan suatu wilayah yang terdiri banyak kabilah yang gemar berperang. Keadaan ini dapat dijelaskan berdasar keadaan geografi yang membentuk karakter masyarakat kabilah di Arabia. Syalabi membagi bangsa Arab ke dalam dua bagian penting, pertama penduduk gurun pasir, kedua penduduk negeri. ${ }^{23}$

\section{B.1. Penduduk Gurun Pasir}

Penduduk gurun pasir adalah kabilah-kabilah yang tinggal di bagian tengah Jazirah Arab seperti di wilayah Najed. Mereka merupakan kabilah-kabilah yang suka berperang. Kabilahkabilah yang sering hidup di gurun pasir adalah Kaum Badui ${ }^{24}$, yang hidup secara nomaden (sering berpindah-pindah tempat tinggal) untuk mendapatkan tempat hidup yang subur untuk memenuhi kebutuhannya dan berternak unta. Dengan karakteristik kehidupan yang terisolasi,

\footnotetext{
${ }^{19}$ F. Budi Hardiman, Menuju Masyarakat Komunikatif (Yogyakarta: Kanisius, 1993), xx.

${ }^{20}$ Ibid., 116.

${ }^{21}$ Ibid.

${ }^{22}$ Abdulsyani, Sosiologi Skematik, Teori, dan Terapan (Jakarta: Bumi Aksara, 2007), 153.

${ }^{23}$ A. Syalabi, Sejarah dan kebudayaan Islam 1, terj. Mukhtar Yahya (Jakarta: Pustaka Al Husna Baru,

${ }^{24}$ Ibid., 9
} 2003), 27. 
hubungan ashabiyah mereka lebih kuat karena di dasari hubungan asahbiyah kekeluargaan dan kekerabatan.

Kaum Badui hidup secara sederhana dan membatasi kebutuhannya hanya pada hal makanan, pakaian, tempat tinggal, dan kebiasaan. ${ }^{25}$ Kaum Badui sebagai penduduk gurun pasir yang tandus, menjadikan mereka orang-orang yang kuat dan pemberani. Mereka ini mempunyai keteguhan jiwa sebagai sifatnya dan keberanian menjadi tabiatnya. ${ }^{26}$ Selain itu, mereka juga mempunyai prinsip kebebasan yang besar dan sangat setia dengan kabilahnya. ${ }^{27}$ Dengan keadaan geografi ekstrim dan tandus, tidak cukup mendukung Kaum Badui untuk menciptakan peradaban yang stabil. Karenanya orang-orang Badui biasa dikenal musuhnya sebagai kaum yang keras dan kejam. ${ }^{28}$

Selain dari pandangan negatif yang sering dialamatkan kepada Kaum Badui, penduduk gurun pasir mempunyai beberapa keistimewaan, pertama, tentang kemurnian nasabnya. ${ }^{29} \mathrm{Hal}$ ini dikarenakan tidak adanya orang asing yang masuk ke daerah tandus itu, maka keturunan mereka sangat terjaga dengan baik. Kedua, Bahasa Arab yang mereka miliki masih murni, tidak tercampur dengan bahasa-bahasa orang asing. Ketiga, Kaum Badui lebih condong kepada memelihara dan menjaga kepentingan dan kemurnian kabilahnya. Keempat, penduduk gurun pasir mempunyai sisi pergaulan sosial yang baik. Menurut Ibn Khaldun, orang Badui lebih mudah menjadi baik daripada penduduk negeri (menetap). ${ }^{30}$ Kelima, orang-orang Badui dikenal mempunyai sikap ramah-tamah (diyāfah), ketabahan (hamāsah), kewibawaan laki-laki (murū'ah) yang dipandang sebagai nilai kekabilahan yang tinggi. ${ }^{31}$ Keenam, mereka juga dikenal setia kepada kawan, ${ }^{32}$ mampu menepati janji, ${ }^{33}$ dan mempunyai tabiat yang jujur dan lugas. Menurut orang-orang Badui perbuatan dusta adalah perbuatan yang hina bagi mereka. ${ }^{34}$ Ketujuh, mereka mempunyai nurani kolektif yang kuat. Artinya, masyarakat primitif seperti kaum Badui mempunyai tipe solidaritas mekanik yang biasanya mempunyai nurani kolektif kuat karena kehidupan mereka bersifat generalis di mana mereka mempunyai beban dan tanggungjawab yang mirip dan dilakukan secara bersama. ${ }^{35}$

Kehidupan Kaum Badui dipenuhi dengan tantangan, keprihatinan, dan jauh dari kemewahan. Hal ini membuat mereka lebih dapat mengontrol nafsu syahwatnya terhadap dunia. Selain itu, mereka juga penduduk yang tidak bisa menyia-nyiakan tamunya, karena mereka masih berpegang teguh pada rasa kehormatan sosial yang tinggi.

\section{B.2. Penduduk Negeri}

Penduduk negeri mempunyai ciri yang berbeda dengan penduduk gurun pasir. Penduduk negeri adalah mereka yang tinggal di daerah subur, yaitu di Jazirah Arab pinggiran atau di beberapa bagian selatan. ${ }^{36}$ Daerah-daerah ini terdapat di beberapa kota, yaitu Bahrain, Oman, Mahrah, Hadramaut, Yaman, dan Hijaz. Penduduk negeri sudah berkehidupan secara

${ }^{25}$ Ibnu Khaldun, Muqaddimah, 142.

${ }^{26}$ Ibid., 147.

${ }^{27}$ Faisal Ismail, Sejarah dan Kebudayaan Islam (Yogyakarta: Bina Usaha, 1984), 4.

${ }^{28}$ Philip K. Hitti, History of The Arabs, terj. Serambi Ilmu Semesta (Jakarta: Serambi Ilmu Semesta, 2006), 31.

${ }^{29}$ Ibn Khaldun, Muqaddimah, 153.

${ }^{30}$ Ibid., 145.

${ }^{31}$ Hitti, History, 31.

${ }^{32}$ Istianah Abu Bakar, Sejarah Peradaban Islam (Malang: UIN Malang Press, 2008), 8.

${ }^{33}$ A. Hasyimi, Sejarah kebudayaan Islam (Jakarta: Bulan Bintang, 1979), 37.

${ }^{34}$ Khalid Muhammad Khalid, Abu Bakar Al-Shiddiq Khalifah Pembawa Kebenaran, terj. Rashid Satari (Bandung: Mizan, 2014), 49-50.

${ }^{35}$ George Ritzer, Teori Sosiologi dari Sosiologi Klasik sampai perkembangan terakhir Postmodern, terj. Saut Pasaribu dkk. (Yogyakarta: Pustaka Pelajar, 2012), 145.

${ }^{36}$ Syalabi, Sejarah, 30. 
menetap dan membentuk kota-kota. Mereka juga sudah membentuk satu institusi kerajaan dan membuat kebudayaan. Ikatan ashabiyah mereka tidak terlalu kuat karena tidak sepenuhnya didasari atas asas kekeluargaan.

Penduduk negeri sering melakukan interaksi sosial, politik, ekonomi, dan budaya dengan bangsa luar untuk memperluas jaringan dan kerja sama bilateral. Jaringan dan kerja sama yang telah dibangun, berakibat pada ramainya pelabuhan-pelabuhan yang mereka miliki sebagai kota rujukan persinggahan dan jual-beli para pedagang dari luar. Akibat daripada itu, kehidupan sosial, ekonomi, politik, dan budaya penduduk negeri lebih stabil dan makmur. Kehidupan yang stabil dan mapan, membuat mereka sering terjerumus ke dalam nafsu syahwat keduniawian. Karena kehidupannya yang stabil dan banyak kenikmatan, mereka mudah dikotori oleh kejahatan dan perbuatan tercela. ${ }^{37}$ Akibatnya penduduk negeri banyak yang kehilangan kontrol diri terhadap hawa nafsu mereka. Selain itu, keadaan geografi yang memberikan mereka banyak kemudahan, membuat penduduk negeri tidak terbiasa hidup keras dalam mendapatkan dan menikmati kehidupan. Akibatnya, penduduk negeri menjadi kaum yang tidak lebih berani dari kaum Badui.

Kerja sama penduduk negeri dengan orang luar ternyata telah memberikan dampak budaya bagi masyarakatnya. Interaksi sosial yang telah terjadi, membuat adanya percampuran budaya bersifat akulturatif ataupun asimilatif. Percampuran budaya ini berakibat pada perubahan bahasa, budaya, perilaku sosial, dan keturunan penduduk negeri. Semua hal itu sudah tidak murni lagi, akibat percampuran budaya dan perkawinan yang terjadi. Dibalik keadaan itu semua, penduduk negeri adalah golongan masyarakat yang telah melewati taraf nomaden menuju tahap pengembangan peradaban yang lebih maju. Sistem sosial dalam kehidupan mereka pun sudah teratur dengan bentuk struktural organik, di mana pembagian kerja atau spesialisasi sudah terjadi yang mencakup individu, kelompok, struktur, atau lembaga. Akibat dari pembagian kerja ini, membuat masyarakat dengan tipe solidaritas organik mempunyai nurani kolektif yang jauh berkurang dibandingkan masyarakat dengan solidaritas mekanik. Namun masyarakat organik masih mempunyai nurani kolektif meskipun dalam bentuk lebih lemah, karena adanya perbedaan-perbedaan individu atau kelompok yang banyak. ${ }^{38}$

\section{Semangat Ashabiyah Kabilah di Jazirah Arab Sebelum Islam}

Penduduk gurun dan penduduk negeri meskipun terlihat berbeda dalam peradabannya, tetapi sebenarnya sama-sama menerapkan semangat solidaritas sosial (ashabiyah). Ashabiyah adalah rasa cinta seseorang terhadap kabilah atau keluarga sedarahnya, yang kemudian menimbulkan sifat alami yaitu saling tolong-menolong dalam suka maupun duka untuk menjunjung tinggi kemuliaan. ${ }^{39}$ Selain itu, ashabiyah juga dapat dipahamai sebagai rasa solidaritas sosial yang menekankan pada kesadaran dan persatuan kelompok. ${ }^{40}$ Dalam struktur kepemimpinan ashabiyah, setiap kabilah dipimpin oleh seorang imam yang biasa disebut Syekh (syaikhul qabilah). Pemimpin kabilah biasanya mempunyai beberapa kompetensi unggulan, seperti pengetahuan, kekuatan, kecerdasan, dan orang yang paling di tuakan dalam kabilah tersebut.

Kabilah-kabilah di Jazirah Arab meskipun mempunyai semangat kekabilahan yang sama, tetapi mereka masih terkotak-kotak oleh garis keturunan atau hubungan darah dalam kabilah masing-masing. Setiap kabilah mempunyai ashabiyah dengan menerapkan sikap tegas membela anggota kabilahnya atau melakukan proteksi penuh untuk menjaga kehormatan saudara sedarahnya. Karenanya perselisihan perorangan anggota kabilah dengan kabilah lain,

\footnotetext{
${ }^{37}$ Ibnu Khaldun, Muqaddimah, 145.

${ }^{38}$ Ritzer, Teori Sosiologi, 150.

${ }^{39}$ Hanna Widayani, "Ashabiyah Ibnu Khaldun dan Relevansinya dengan Nasionalisme di Indonesia," Manthiq, 2, no 2, (2017): 149-162.

${ }^{40}$ John L. Esposito (Ed.), Ensiklopedi Dunia Islam Modern, Jilid I (Bandung: Mizan, 2001), 198.
} 
dapat menimbulkan konflik antar kabilah yang sering kali berlangsung sangat lama. ${ }^{41}$ Karena perasaan kekeluargaan yang kuat di setiap kabilah, proses hubungan interaksi mereka memang sering menuju arah ekstrim menjadi pertikaian dan terkadang dapat merusak struktur interaksi sosial di antara kabilah-kabilah. Tidak jarang interaksi sosial mereka menuju proses sosial yang destruktif.

Kabilah-kabilah di Jazirah Arab mempunyai semangat ashabiyah dan hidup berkelompok karena dipaksa oleh lingkungan geografis. Dengan hidup berkelompok mereka akan dapat bertahan hidup dari serangan kabilah-kabilah lain yang sedang mencari daerah subur dan memperluas kekuasaan. Kelompok kabilah di Jazirah Arab, khususnya kabilah-kabilah yang hidup di gurun pasir (nomaden), sering memperebutkan wilayah subur karena ingin memanfaatkan sumber daya alam dan sebagai tempat berternak hewan. Oleh karena itu, tanpa adanya solidaritas sosial yang kuat dan dibangun secara internal oleh masing-masing kabilah, mereka tidak akan bisa menghadapi kabilah lain yang sedang menyerang wilayah kekuasaannya.

Dari sebab-sebab yang telah diterangkan di atas, dapat ditarik satu sintesa bahwa, seseorang yang hidup sendirian (tidak berkelompok) tidak mungkin untuk bertahan di padang pasir Jazirah Arab, karena mereka akan selalu diserang kelompok kabilah lain yang berkeinginan mendapatkan wilayah kekuasaan yang subur dan kehormatan. Akibatnya, menjadi kewajiban bagi kabilah-kabilah di Arab hidup berkelompok sebagai bentuk perlindungan diri, perlindungan wilayah, dan perlindungan nasabnya.

Kelompok kabilah di Jazirah Arab untuk menangkal serangan kabilah lain, akhirnya membentuk kelompok pasukan penjaga yang terdiri dari para pemuda yang gagah, pemberani, dan mempunyai keterampilan dalam berperang. ${ }^{42}$ Para pemuda ini diambilkan dari anak keturunan masing-masing kelompok kabilah. Atas rasa satu darah dan keturunan, para pemuda penjaga ini mampu bertarung mati-matian. Kelompok pemuda ini juga lebih mementingkan kepentingan kelompoknya daripada yang lain, karena rasa cinta kepada keluarga dan keturunannya. Ashabiyah dapat dikatakan telah membentuk kekuatan persatuan yang mampu melindungi dan mempercepat kemenangan sosial-ekonomi dan sosial-politik satu kelompok ashabiyah di antara kelompok ashabiyah lainnya. ${ }^{43}$

Ashabiyah secara sosiologis dapat menjadi peredam pertentangan antar sesama anggota keluarga (keturunan). Rasa solidaritas sosial yang timbul dalam satu kelompok kabilah, selanjutnya menimbulkan sifat tolong-menolong dan gotong royong. ${ }^{44}$ Solidaritas sosial yang salah satu kabilah ciptakan dengan kuat dan dipersenjatai dengan kekuatan perang yang hebat, akan membuat musuh segan dan takut untuk melakukan serangan. Karena semakin solid kelompok kabilah tersebut, maka semakin besar motivasi dan kekuatan mereka dalam berperang.

Solidaritas sosial yang tercipta dalam satu konsep ashabiyah, berakibat adanya satu tujuan yang sama. ${ }^{45}$ Representasi dari tujuan ini, bahwa dalam satu kelompok kabilah mempunyai keinginan untuk memuliakan sesama anggotanya. Mereka membenci penindasan yang dilakukan kelompok kabilah lain terhadap kelompoknya, karena ada rasa persatuan di mana ada satu anggota kabilah yang merasakan kesakitan, maka semua anggota ikut merasakan kesakitan yang sedang dirasakan orang tersebut. Satu kabilah atau keturunan dapat dipastikan membantu sesama anggotanya, apabila hak-hak saudara sedarahnya telah dilanggar kabilah

\footnotetext{
${ }^{41}$ Siti Maryam dkk. (Ed.), Sejarah Peradaban Islam dari Masa Klasik Hingga Modern (Yogyakarta: LESFI, 2009), 19.

${ }^{42}$ Ibnu Khaldun, Muqaddimah, 150-151.

${ }^{43}$ Al-Khudhari, Filsafat Sejarah, 161.

${ }^{44}$ Ibid., 160.

${ }^{45}$ Ibnu Khaldun, Muqaddimah, 151.
} 
lain. ${ }^{46}$ Oleh karena itu, panggilan perang sering terjadi dalam ashabiyah garis keturunan umum maupun dalam garis keturunan khusus.

Dalam dua klasifikasi garis keturunan ashabiyah, garis keturunan khusus mempunyai rasa persatuan kekeluargaan yang lebih erat. Pembelaan bahkan sampai terjadinya peperangan, semata-mata dilakukan untuk menghindari kehinaan yang dapat ditimbulkan. Karenanya, ashabiyah yang ada dalam satu kabilah sesungguhnya mempunyai pengaruh potensial terhadap tindakan setiap anggotanya. ${ }^{47}$ Semangat ashabiyah mengisyaratkan bahwa setiap individu harus loyal terhadap kabilahnya, karena kabilah yang terikat dengan solidaritas yang kuat yang dapat hidup di wilayah padang pasir Jazirah Arab. ${ }^{48}$ Sistem sosial inilah yang nantinya membantu perluasan kekuasaan Nabi Muhammad saw. dalam menyebarkan ajaran Islam di seluruh Jazirah Arab.

\section{Internalisasi Prinsip-prinsip Islam dalam Ashabiyah dalam Menunjang Kekuasaan Nabi Muhammad SAW \\ D.1. Ashabiyah dan Islam}

Perilaku keberagamaan bangsa Arab sebelum Islam, memperlihatkan bahwa mereka menjadi seorang hamba yang taat pada ajaran agama Nabi Ibrahim (tauhid), tetapi di sisi lain bangsa Arab juga menyembah berhala. ${ }^{49}$ Penyembahan berhala ini yang nantinya akan membawa mereka kepada jalan kemusyrikan. Salah satu kebiasaan orang Arab masa itu, ketika mereka akan meninggalkan Makkah, biasanya membawa batu dari Haram Ka'bah sebagai rasa hormat dan kecintaannya terhadap tanah suci. Mereka menjadikan batu itu sebagai media dan perumpamaan Ka'bah, sehingga mereka dapat melakukan thawaf atas batu itu, meskipun mereka masih melakukan ibadah haji dan umrah ke Makkah secara langsung. Namun dalam perjalanan sejarah, tradisi itu banyak membawa orang-orang Arab membuat batu-batu besar yang dimuliakan dan menyandingkannya dengan Ka'bah. Batu-batu yang mereka buat, kemudian disembah seperti halnya menyembah Tuhan. Meskipun sebenarnya penyembahan berhala ini adalah satu ungkapan perantara penyembahan terhadap Allah swt. ${ }^{50}$

Penyelewengan ajaran keagamaan semakin terlihat ketika penduduk Arab yang mempunyai keinginan atau hendak melakukan pekerjaan penting, sering meminta petunjuk kepada penjaga Baitullah dengan mempersembahkan korban hewan atau manusia. Hal ini dilakukan agar keinginan mereka cepat terkabul. Perilaku penyelewengan lain yang lebih kejam adalah kebiasaan Bani Asad dan Bani Tamim ${ }^{51}$ yang sering mengubur bayi perempuan secara hidup-hidup karena di khawatirkan nanti kehormatannya bisa direbut orang jahat atau musuh. ${ }^{52}$ Akan tetapi, kebudayaan dan tradisi yang menyimpang ini, akhirnya dapat dihilangkan sedikit demi sedikit setelah Islam yang dibawa Nabi Muhammad SAW menyebar di Jazirah Arab.

Selain hal di atas, kehidupan sosial bangsa Arab sebelum Islam juga dipengaruhi oleh ashabiyah yang sering membawa kabilah-kabilah di Arab dalam peperangan dan kehancuran. Namun, Nabi SAW dengan ajaran Islamnya telah membuat ashabiyah menjadi satu hal yang lebih transformatif secara akhlak, khususnya bagi para anggota kelompok kabilah di sana. Oleh

${ }^{46}$ Ibid., 152.

${ }^{47}$ Albert Hourani, Sejarah Bangsa-bangsa Arab, terj. Irfan Abubakar (Bandung: Mizan, 2004), 232.

${ }^{48}$ Ibid., 150.

${ }^{49}$ Syalabi, Sejarah, 55-56.

${ }^{50}$ Ibid., 58. Baca Q.S. Az Zummar ayat 3.

${ }^{51}$ Jurji Zaydan, Taarikh al-Tamaddun al-Islami, jld. 5 (Beirut: Syari'), 578. hlm. Lihat juga M. Abdul Karim, Sejarah Pemikiran dan Peradaban Islam (Yogyakarta: BAGASKARA, 2014), 51.

${ }^{52}$ Syalabi, Sejarah, 61. Dalam Q.S. al-Nahl: 58-59, dikatakan bahwa bangsa Arab sebelum Islam apabila mendengar kabar istrinya melahirkan anak perempuan, maka para suami akan marah besar. Karena itu adalah sebuah aib maka mereka menyembunyikannya atau bahkan menguburnya hidup-hidup. 
karena itu antara ashabiyah dan Islam sebenarnya saling pengaruh-mempengaruhi dalam berbagai pola kehidupan bangsa Arab.

Pertama, peran agama Islam dalam transformasi nilai-nilai ashabiyah. Bangsa Arab yang dikenal keras, ambisius, dan sering berperang dalam memperebutkan kekuasaan, telah dilunakkan oleh Islam yang dibawa Nabi saw. Proses dakwah secara diplomatis dan komunikatif cerdas yang dilakukan oleh Nabi saw, banyak menimbulkan berbagai keberhasilan dalam proses perubahan sosial di Jazirah Arab. Terlebih perubahan mendasar mengenai akhlah yang lebih terpuji. Nabi saw. telah membawa Islam menjadi wadah bagi bangsa Arab guna memperbaiki berbagai aspek kehidupan di sana. Nabi saw dengan perangai yang lemah lembut dalam proses komunikasi kepada umat, selanjutnya mampu meredam mereka dari segala perangai buruk yang biasa mereka lakukan. ${ }^{53}$ Pertentangan-pertentangan antar kabilah di Jazirah Arab pun dapat dihilangkan. Akhirnya mereka dapat dipersatukan dalam semangat keagamaan yang sama yaitu Islam yang dibawa oleh Nabi Muhammad saw. Nabi saw. telah melunakkan kebiasaan berperang antar suku di berbagai kabilah di Jazirah Arab. Beliau juga mampu membuat kabilah-kabilah di sana bersatu dalam sistem ashabiyah yang kuat. ${ }^{54}$ Tentunya persatuan ashabiyah mereka tidak hanya berdasar pada asas kekeluargaan, tetapi pada asas persatuan agama. Lebih jauh lagi, Nabi saw berdasar wahyu Allah swt telah mengubah kabilah-kabilah agar meninggalkan sifat-sifat tercela dan mulai menjalankan sifat-sifat baik sebagai fitrah manusia yang sudah digariskan oleh Allah swt. Seruan Nabi saw mengenai perbaikan akhlak dan beribadah kepada Allah swt mereka lakukan dengan baik.

Kedua, peran ashabiyah dalam kehidupan keagamaan. Nabi SAW dalam gerakan menyebarkan ajaran Islam, tentu membutuhkan anggota atau umat sebagai basis pendukung. Nabi SAW yang membawa kebenaran Allah SWT, dari awal telah mampu menyatukan bangsabangsa Arab dalam satu ashabiyah yang berbasis semangat persatuan Islam. Selain itu, Nabi SAW juga menyerukan kepada seluruh umatnya untuk menentang kejahatan dan kezaliman.

Setelah adanya internalisasi prinsip Islam dalam Ashabiyah, selanjutnya semangat ashabiyah berperan penting dalam penyebaran agama baru ini. Pernyataan Ibnu Khaldun yang dikutip dari hadits shahih "Allah tidak mengutus seorang Nabi pun kecuali ia berada dalam penjagaan kaumnya". ${ }^{55}$ Artinya, sistem sosial ashabiyah yang dianut oleh masyarakat Jazirah Arab telah berperan menopang penyebaran dan eksistensi agama Islam. Dan atas kehendak Allah swt, ashabiyah menjadi basis kekuatan sosial-keagamaan untuk mendukung dakwah Nabi saw. Dari semua alasan itu, bangsa Arab tidak akan mampu meraih kesuksesan kecuali atas dasar ajaran agama Islam. ${ }^{56}$

Satu hal yang kurang menggembirakan karena kuatnya budaya ashabiyah di kalangan bangsa Arab, membuat ajaran Nabi saw. mengenai "kesetaraan" banyak mendapat pertentangan setelah Nabi saw. wafat. Kebanggan terhadap keturunan nyatanya tetap kuat, serta konsep kesetaraan telah mengalami degradasi secara evolutif. ${ }^{57}$ Beberapa dari mereka bahkan saling klaim sebagai keturunan Nabi saw. agar mendapatkan prestis sosial yang tinggi di mata masyarakat.

Berbagai pertentangan tentang kesetaraan sudah dimulai dalam beberapa fase. Fase pertama, yaitu masa Khalifah Umar bin Khattab dalam hal pembagian ghanimah. Berlanjut pada masa Khalifah Uṡmān bin Affān saat penunjukkan pejabat penting di pemerintahannya yang dianggap oleh beberapa ahli sebagai sikap nepotis, meskipun ada beberapa ahli yang menyebutkan sikap Usmān sebagai sikap yang wajar dan proporsional. Fase kedua, saat

\footnotetext{
${ }^{53}$ Ibid., 181.

${ }^{54}$ Ibid., 182.

${ }^{55}$ Ibnu Khaldun, Muqaddimah, 194.

${ }^{56}$ Al-Khudhari, Filsafat, 161.

${ }^{57}$ Reuben Levy, Susunan Masyarakat Islam, terj. Ludjito (Jakarta: Pustaka Firdaus, 1986), 60.
} 
terjadinya perpecahan umat Islam pada masa Khalifah 'Alī bin Abī Ṭālib, yang nantinya menjadikan umat Islam terpecah dalam beberapa kelompok besar. Fase ketiga yaitu sebagai fase puncak perpecahan, adalah pada masa Dinasti Umayyah dan Dinasti Abbasiyah, di mana mereka saling klaim sebagai keturunan atau kabilah yang paling berhak menjabat sebagai khalifah. Oleh karenanya kesuksesan Nabi saw. dalam berkuasa dan berdaulat atas nama Islam, secara sosial dan politik membuat hubungan kekeluargaan dengan Nabi saw. dianggap sebagai ukuran kemuliaan. Hal ini pun masih bisa kita rasakan sampai sekarang, seperti di Indonesia.

\section{D.2. Ashabiyah dan Politik}

Ashabiyah yang berlandaskan prinsip dan nilai Islam, selanjutnya mempunyai pengaruh besar dalam bidang politik bangsa Arab. Agama menjadi pagar bagi masyarakat untuk menyingkirkan perasaan buruk sangka dan mengarahkan kepada kebenaran. Kesatuan ashabiyah yang kuat dengan ditunjang kelompok pasukan elite dan kesatuan tujuan yang sama, ternyata mampu membawa Nabi saw. bersama kabilah-kabilah di sana menjadi penguasa dan mampu mendirikan sebuah negara Islam. ${ }^{58}$ Ashabiyah menurut Ibnu Khaldun memang mempunyai peran besar dalam pembentukan negara, ${ }^{59}$ karena penguasa atau negara tidak bisa besar tanpa adanya dukungan rakyatnya.

Kesatuan ashabiyah yang didasarkan pada tujuan yang sama, seperti tujuan untuk menghilangkan kebatilan dan menjunjung tinggi kebenaran atas perintah Allah swt, membuat kekuasaan politik mereka semakin kuat. Persatuan sosial-keagamaan berdasar ashabiyah dan Islam ini pula yang membuat kekuasaan Nabi SAW semakin luas. Karena orang tidak dapat mendirikan suatu negara tanpa adanya persatuan dan solidaritas umat yang kuat. ${ }^{60}$

Secara politis tujuan akhir dari ashabiyah yaitu kepemimpinan dan kekuasaan yang menimbulkan kedaulatan. Karena tujuan mulia ini, Nabi saw. menempatkan Islam ke dalam konsep ashabiyah untuk membentengi kabilah-kabilah di Arab agar tidak terjerumus ke dalam konflik politik dan ketidakadilan sosial. Untuk mencegah perpecahan dan peperangan berbagai kelompok ashabiyah yang ada di Jazirah Arab, diharuskan ada satu ashabiyah yang lebih unggul daripada ashabiyah yang lain. ${ }^{61}$ Maka ashabiyah paling kuat yang akan memimpin ashabiyah lainnya dan berkuasa secara de facto. Dengan demikian kepemimpinan terpusat pada salah satu ashabiyah paling kuat.

Dalam konsep ashabiyah unggulan, mereka yang bekuasa nantinya dapat membawahi ashabiyah lain sebagai bawahannya. Ashabiyah yang berada di bawahnya kemudian mencari ashabiyah lain. Apabila ashabiyah ini mempunyai tujuan yang sama dengannya, maka kedudukan mereka setara. Namun, jika ashabiyah satu dapat mengalahkan ashabiyah lain, maka yang kalah memberikan dukungannya kepada yang menang untuk menuntut kedaulatan yang lebih tinggi (mereka bergerak sebagai oposisi). Siklus ini terjadi terus sampai pihak oposisi bisa sama kedaulatannya dengan negara (penguasa) yang sedang berkuasa. ${ }^{62}$

Nabi saw. pada waktu itu diuntungkan karena mempunyai ashabiyah unggul di dalam dirinya, keluarganya, dan keturunannya untuk mencegah kehancuran dan perpecahan umat. Akhirnya beliau mampu menyatukan kelompok ashabiyah yang berbeda-beda ke dalam satu kelompok ashabiyah besar yang dipimpinnya. Terlebih beliau dapat menjauhkan umat dari agresifitas ego dan sifat kebinatangan untuk memenuhi kepentingannya sendiri. Atas pertimbangan berbagai keunggulan Nabi saw, beliau diangkat secara de facto dan de jure

\footnotetext{
${ }^{58}$ Ibnu Khaldun, Muqaddimah, 156, 157 dan 192.

${ }^{59}$ Muhammad Azhar, Filsafat Politik; Perbandingan Antara Islam dan Barat (Jakarta: PT Raja Grafindo Persada, 1996), 102.

${ }^{60}$ Hanna Widayani, "Ashabiyah Ibnu Khaldun dan Relevansinya dengan Nasionalisme di Indonesia," Manthiq, 2, no 2, (2017): 149-162.

${ }^{61}$ Ibnu Khaldun, Muqaddimah, 166.

${ }^{62}$ Ibid., 167.
} 
sebagai pemimpin umat Islam dan pemimpin ashabiyah di Jazirah Arab. Pengangkatan ini berdasar pada kebutuhan seorang pemimpin yang kuat di antara lainnya untuk memimpin umat. Oleh karena dalam suatu kelompok pasti terdapat berbagai macam bentuk interaksi sosial, maka mereka membutuhkan al-Waji' (orang yang membagi). ${ }^{63}$ Artinya, harus ada satu kekuatan utama yang memimpin kelompok ashabiyah menuju satu perwujudan kekuasaan yang adil dan mensejahterakan semua umat.

\section{E. Penutup}

Perilaku kehidupan bangsa Arab secara umum dibedakan atas cara mereka memperoleh kehidupan. Penduduk yang hidup di padang pasir menjadi penduduk yang lebih kuat dan tangguh dalam menghadapi berbagai rintangan. Kehidupan mereka juga lebih terlihat seadanya dan menjaga kemurnian sistem sosial, politik, budaya, maupun keluarganya. Berbeda dengan kehidupan penduduk negeri yang sudah menetap dan membentuk peradaban. Mereka adalah sosok penduduk yang jauh dari kemurnian alami kehidupan. Mereka sudah terkontaminasi dengan perilaku cinta terhadap dunia dan rentan dengan serangan. Segala segi kehidupan penduduk negeri telah bercampur dengan orang asing dan mengubah mereka menjadi masyarakat yang tidak alami.

Kedua klasifikasi penduduk yang berada di Jazirah Arab ternyata sama-sama menerapkan konsep ashabiyah di dalam kehidupan keluarga dan sosialnya. Ashabiyah telah menjadi acuan sosial masyarakat Arabia sebelum Islam. Dengan semangat dan persatuan ashabiyah, kelompok-kelompok kabilah di Jazirah Arab dapat bertahan hidup di kerasnya gurun pasir yang tandus. Tidak heran kelompok-kelompok kabilah ini, sering berperang oleh karena perebutan wilayah kekuasaan subur ataupun masalah-masalah pribadi. Kesatuan kelompok dalam konsep ashabiyah menjadi pegangan pokok bagi kabilah-kabilah di sana untuk bertahan hidup.

Kesatuan dan persatuan ashabiyah yang telah tercipta sebelumnya, membuat ajaran Islam yang dibawa oleh Nabi SAW menjadi mudah tersebar luas. Kabilah-kabilah penguasa khususnya kabilah yang menjadi nasab Nabi SAW, ikut mendorong suksesi dakwah Nabi SAW, meskipun harta dan nyawa taruhannya. Nyatanya pada masa itu, ashabiyah telah menyatu dengan etika Islam dan etika politik Islam untuk mencapai kedaulatan dan kemakmuran bersama. Hal ini juga yang sebenarnya dicita-citakan oleh kelompok ashabiyah di Jazirah Arab. Meskipun ikatan persaudaraan dalam konsep ashabiyah dianggap paling kuat pada masa Nabi SAW, tetapi hal ini nantinya akan mengakibatkan pertentangan antar kelompok kabilah di Jazirah Arab dan menjadi cikal bakal kehancuran kerajaan-kerajaan Islam setelah wafatnya Nabi SAW.

Berdasarkan temuan penelitian ini, penulis memandang perlunya pembahasan lebih lanjut mengenai alasan dan dasar sosial, politik, dan kultural mengenai perubahan artian ashabiyah setelah wafatnya Nabi saw. Hal ini bisa dilakukan dengan melakukan pencarian dan pengumpulan sumber naskah, dokumen sezaman, atau menggunakan sumber sekunder yang berasal dari keterangan buku-buku babon. Sehingga nantinya bisa dituliskan peristiwa sejarah sosial secara kronologis, sistematis, dan logis.

\section{DAFTAR PUSTAKA}

Abdulsyani. Sosiologi Skematik, Teori, dan Terapan. Jakarta: Bumi Aksara, 2007.

Abdurrahman, Dudung. Metodologi Penelitian Sejarah Islam. Yogyakarta: Ombak, 2011.

Azhar, Muhammad. Filsafat Politik; Perbandingan Antara Islam dan Barat. Jakarta: PT Raja Grafindo Persada, 1996.

\footnotetext{
${ }^{63}$ Muh. Ilham, "Konsep 'ashabiyah Dalam Pemikiran Politik Ibnu Khaldun” Jurnal Politik Profetik, 04, no. 1 (2016): 1-13.
} 
Bakar, Istianah Abu. Sejarah Peradaban Islam. Malang: UIN Malang Press, 2008.

Fajar, Abbas Sofwan Matlail. "Perspektif Ibnu Khaldun Tentang Perubahan Sosial." SALAM: Jurnal Sosial dan Budaya Syar-i 6, no. 1 (2019): 1-12.

Hardiman, F. Budi, Menuju Masyarakat Komunikatif. Yogyakarta: Kanisius, 1993.

Hasyimi, A. Sejarah kebudayaan Islam. Jakarta: Bulan Bintang, 1979.

Hitti, Philip K. History of The Arabs. Terj. Serambi Ilmu Semesta. Jakarta: Serambi Ilmu Semesta, 2006.

Hourani, Albert. Sejarah Bangsa-bangsa Arab. Terj. Irfan Abubakar. Bandung: Mizan, 2004.

Ilham, Muh. "Konsep 'ashabiyah Dalam Pemikiran Politik Ibnu Khaldun" Jurnal Politik Profetik, 04, no. 1 (2016): 1-13.

Ismail, Faisal. Sejarah dan Kebudayaan Islam. Yogyakarta: Bina Usaha, 1984.

Karim, M. Abdul. Sejarah Pemikiran dan Peradaban Islam. Yogyakarta: BAGASKARA, 2014.

Khaldun, Ibnu. Muqaddimah. Terj. Ahmadie Thoha. Jakarta: Pustaka firdaus, 2008.

Khalid, Muhammad Khalid. Abu Bakar Al-Shiddiq Khalifah Pembawa Kebenaran. Terj. Rashid Satari. Bandung: Mizan, 2014.

Al-Khudhari, Zainab. Filsafat Sejarah Ibnu Khaldun. Terj. Ahmad Rofi' Utsmani. Bandung: Pustaka, 1979.

Levy, Reuben. Susunan Masyarakat Islam. Terj. Ludjito. Jakarta: Pustaka Firdaus, 1986.

Maryam, Siti dkk. (Ed.). Sejarah Peradaban Islam dari Masa Klasik Hingga Modern. Yogyakarta: LESFI, 2009.

Ritzer, George. Teori Sosiologi dari Sosiologi Klasik sampai perkembangan terakhir Postmodern. Terj. Saut Pasaribu dkk. Yogyakarta: Pustaka Pelajar, 2012.

Saumantri, Theguh, and Abdillah Abdillah. "Teori Ashabiyah Ibnu Khaldun Sebagai Model Perkembangan Peradaban Manusia" Jurnal Tamaddun: Jurnal Sejarah dan Kebudayaan Islam 8, no. 1 (2020).

Syafrizal. "Konsep 'Ashabiyah Ibn Khaldun dalam Penguatan Nilai Nasionalisme di Indonesia". Skripsi Fakultas Syariah dan Hukum. Universitas Islam Negeri Sumatera Utara, 2017.

Syalabi, A.. Sejarah dan kebudayaan Islam 1. Terj. Mukhtar Yahya. Jakarta: Pustaka Al Husna Baru, 2003.

Widayani, Hanna, "Ashabiyah Ibnu Khaldun dan Relevansinya dengan Nasionalisme di Indonesia," Manthiq, 2, no 2, (2017): 149-162.

Zaydan, Jurji. Taarikh al-Tamaddun al-Islami, jld. 5. Cairo: Hindawi, 2013. 